\title{
Entrevista com Bogdan GHIU ${ }^{1}$
}

Alea: A ignorância brasileira sobre a literatura e a cultura romenas é tal que torna dificil para nós começar esta entrevista. Mas, talvez, pudéssemos começar por uma similaridade, pelo fato de o Brasil e a Romênia serem países periféricos. O senhor acredita que o caráter periférico romeno teria uma especificidade? Qual seria?

Bogdan Ghiu: Mesmo após um simples e rápido olhar sobre as questôes que você teve a amabilidade de me dirigir, acredito que nos entenderemos, que já nos entendemos maravilhosamente bem: vocês falam e descrevem a situação contemporânea da cultura, de sua cultura, da cultura brasileira contemporânea, em termos e com uma visão muito próximos, em um tom quase idêntico ao que utilizamos em meu país, com relação à cultura romena. Poderíamos nos entender apenas pela distância: a distância entre nós, entre a Romênia e o Brasil, e as múltiplas distâncias que sentimos com relação aos centros, àquilo que continuamos a chamar "o Ocidente", mesmo que, para vocês, a noção de "Ocidente" deva soar bastante curiosa... É verdade, eu acredito também, que nunca somos verdadeiramente diferentes e separados da mesma maneira. Vocês, por exemplo, quero dizer, o Brasil, a cultura brasileira é - ou deveria ser - maior, mesmo que mais afastada. Nós, os romenos, somos menores, mas mais próximos, já europeus, ainda que de segunda categoria. Vocês são quase um continente, um planeta inteiro, vocês poderiam fazer concorrência e inverter a atração, a gravitação cultural (mas não apenas) do Ocidente. Nós somos menores e mais próximos, então, temos o hábito de alimentar o "Centro" com indivíduos e personalidades criadoras excepcionais. O que é

\footnotetext{
${ }^{1}$ Bogdan Ghiu nasceu em Bucareste em 1958 e é um dos mais importantes intelectuais romenos contemporâneos. Ganhou inúmeros prêmios como poeta, ensaísta, jornalista e tradutor. Trabalhou como consultor e realizador de programas de televisão de canais públicos e privados. É colaborador das principais publicaçóes culturais da Romênia. Além das diversas coletâneas de poemas e de ensaios, traduziu escritores e filósofos franceses importantes como Sade, Baudelaire, Artaud, Michel Leiris, Bataille, Deleuze, Derrida, Foucault, Baudrillard, entre outros. E-mail: < bogdan.ghiu@gmail.com>. Entrevista realizada por email em janeiro de 2013 por Marcelo Jacques de Moraes e Fabio Ackcelhud Duráo, editores da revista.
} 
sempre estranho aqui é que temos o hábito de nos encontrar entre vizinhos imediatos - por exemplo, romenos, búlgaros, magiares -, mas não aqui, localmente, diretamente, mas antes em Paris ou em Londres e, mais recentemente, em Berlim. Nós seremos sempre interessantes para as metrópoles pela nossa energia, pela nossa estranheza e pela nossa "selvageria", pelo nosso capital de agressividade, de sonho, de jogo, quer dizer, como diriam Deleuze e Guattari, falando justamente de Kafka, pela nossa marginalidade, pela nossa menoridade. Por exemplo, desde alguns anos, certos autores romenos bastante jovens entraram na produçáo global de ficção normatizada que é chamada de romance, no "storytelling" mundial. De toda a produção literária ou, digamos mais amplamente, textual, a única permitida e encorajada, como mercadoria cultural global, aquela que marca justamente nosso caráter periférico é a ficção, o romance, a "story", a "His-Story", não o ensaio, a análise, a filosofia, que continuam a se desenvolver somente no "centro", nos centros do Ocidente, como produção ideológica, de esquemas de descrição-produção, de normas, de "palavras de ordem". Considero, então, que para além das eventuais particularidades e especificidades da marginalidade, da existência periférica, seria necessário procurar extrair o que é comum, o que permanece universal enquanto produção de menoridade, de "menoração" (no sentido de Kant).

Alea: A cultura brasileira se encontra hoje em crise. Após o fim da ditadura militar (1964-1989) e com a consolidaçâo da indústria cultural, um paradoxo parece ter se instalado: de um lado, as condiçôes são favoráveis à produção cultural porque não há mais censura e há recursos, que apesar de não serem magnificos, não são insignificantes; de outro lado, existe uma certa acomodação, uma apatia que se traduz por uma certa falta de audácia e pela inexistência (ou ao menos pela escassez) de trabalhos verdadeiramente inovadores. A situação é similar na Romênia? Como o senhor julga a produção cultural na Romênia desde a queda de Ceausescu?

B.G.: Não, na Romênia, agora, não se fala em termos de crise para a cultura, somente as instituiçóes são criticadas, então, finalmente, sim, a situação é a mesma. As jovens geraçôes, sobretudo, se contentam com o exercício normal, civil, menor da liberdade, o que acaba neutralizando, ou, mais uma vez, "menorando", depreciando a própria liberdade. Mas não temos o direito de criticar isso! Não 
se pode jamais preferir a censura que provoca o orgulho criativo à apatia atual. Em estado de pretensa normalidade civil, de não provocação política, tudo se achata, e é necessário tentar "aterrorizar" a atmosfera, o que eu tento fazer quase o tempo todo (por exemplo, com os livros que intitulo Dadasein, ou La Contre-Crise [A Contra-Crise], ou L'Inconstruction [A Inconstrução], ou Telepitecapitalisme [Telepitecapitalismo] etc.), mas minhas provocaçôes são, na maioria dos casos, pura e simplesmente evitadas, não recebidas. Ao mesmo tempo, eu me próbo de criticar tudo isso, eu prefiro continuar a provocar, a subir o tom, literalmente. Não, não experimentamos mais, chegamos ao ponto de julgar esse gesto como anacrônico, pertencente à gesticulação das vanguardas históricas. Mas, considerando os mais de vinte anos desde a queda de Ceausescu, eu acho que o balanço deveria ser julgado positivo em sua maior parte. Após um século XX destruidor, a espécie humana parece cansada e, sobretudo, talvez, assustada consigo mesma, e sua nova sabedoria consiste numa espécie de modéstia, de mimetismo, de estupidez e de sonos aparentes (o que eu tentei analisar, na arte contemporânea, em La vie d'après la survie [A vida depois da sobrevivência]). Assim, deveríamos, talvez, nos contentar em sermos pequenos, mas estarmos vivos... Eu não me contento só com isso, mas observo e respeito, por decência política, o novo instinto de comodidade, do prazer imediato, do "se sentir bem" (consigo mesmo) sem muito esforço, a poética do menor esforço na criação contemporânea, na witz-arte atual, atitudes que eu, pessoalmente, não adoto. Mas é justamente essa diminuição, esse eufemismo do ser que faz o clima geral da época, que não é despreocupada, mas também não é alerta, nem dramática, e tenta redescobrir a vida mesmo nas condiçóes de reduçáo, de des-intensificação da vida. É como no supermercado: há de tudo - romance, poesia, teatro, artes visuais e performáticas etc. -, porém, como bens de consumo cultural. Uma diminuição da cultura também: talvez, a noção de "cultura", de "culturalização" de tudo, como transformação em "bens de consumo cultural", seja o processo que explique tudo isso. Cultura demais, menos cultura. Ou: cultura demais, menos criação, menos novidade, mais reciclagem etc. É a imediatidade, a continuidade, o fluxo o que conta. De qualquer forma, e de um outro ponto de vista, acredito que as artes da linguagem verbal vivem, hoje, uma perda histórica de velocidade, até mesmo a narração, a ficção tran- 
sitam mais facilmente pela imagem-fluxo: a literatura abandona a língua, se podemos dizer.

Em mais de vinte anos, em breve um quarto de século, a literatura romena percorreu, por todas as geraçôes e em todas as frentes, uma longa cruzada de reapropriaçáo do eu, do homem individual, desde sempre exposto a todas as expropriaçóes possíveis, e, portanto, em breve, assim espero, o conflito com o outro expropriador se desenvolverá na intimidade do pretenso "si mesmo". A única saída que entrevejo, que, mais precisamente, desejo para esta soma de pequenos realismos (o homem em todos os seus detalhes, em todas as suas realidades, hiperrealidades, irrealidades, etc., o homem em sua imediatidade sonhada, fantasiada para si, o homem imediato) que é a literatura romena atual, seria uma (infra-)politização imanente do si, a batalha de todas as batalhas.

Alea: O senhor tem uma relação significativa com a cultura e o pensamento franceses, estudou na França, traduziu muita coisa do francês (Foucault, Deleuze, Derrida, Bourdieu, Baudrillard, Baudelaire, Duras...). Por outro lado, intelectuais romenos importantes viveram na França e até mesmo escreveram em francês (Cioran, Eliade, Ionesco, Ghérasim Luca...). Qual a importância desse vinculo com a França para a produção intelectual romena contemporânea em geral e, particularmente, para o seu próprio trabalho como escritor?

B.G.: As fontes francesas foram determinantes para a cultura e, em geral, para a modernidade romena. Agora, como em todos os lugares do mundo, tudo aquilo que é francês está perdendo influência; assim, certos autores e uma certa tradição francesa podem ser cultivados como resistência ou como desvio às normas que são, atualmente, de origem anglo-saxônica. $\mathrm{O}$ francês (não somente a língua), mesmo que os franceses não estejam prontos para reconhecer, tornou-se menoridade, e, por isso, um aliado estratégico e tático para uma obra comum de resistência. Eu sempre concebi minha atividade de tradutor em termos políticos, como um tráfico ilegal de armas, ou de armas ilegais: os conceitos e as análises são armas e sementes. Neste momento, aqui na Romênia, Ghérasim Luca não está no mesmo plano que Cioran, Eliade ou Ionesco, que estão saturados no mercado local, para sua própria infelicidade, aliás. Luca continua por ser descoberto na Romênia, assim como muitas outras imensas vozes das vanguardas romenas, como 
Geo Bogza, por exemplo, que continuam por ser redescobertas. Por outro lado, os autores franceses que traduzo tornaram-se referências canônicas para as jovens geraçóes de intelectuais e artistas através das citaçóes anglo-saxônicas, e esses jovens têm a surpresa de encontra-los já traduzidos para o romeno. Ao mesmo tempo, eu acredito que um intelectual e um poeta não podem se privar da tradução, o gesto de traduzir é a metáfora em ato: fazer (inter)vir o distante, o diferente, abrir o mesmo à diferenciação, à mestiçagem, às trocas, provocá-lo a testar e a legitimar a si mesmo.

Alea: O senhor tem uma vasta produção como poeta, ensaista e tradutor. Como vê as relaçóes entre as diferentes práticas de escrita?

B.G.: É o poeta, a poesia, o meta-infra-ato poético (não lírico!) que unifica tudo isso, a poesia como estrutura gesticuladora da vida, como ato político unificador, pontifical, não (apenas) como escrita propriamente poética, lírica, mas o poeta sem lirismo, a-lírico, i-lírico (um tipo de Ilírico), des-lírico... Há lirismo demais (mesmo que a-lírico) na poesia romena atual! No que me diz respeito, eu faço uma espécie de poesia... constitucional, para aproximar a poesia da escrita da lei, da lei de constituição de cada aspecto de humanidade... A época atual, ou a futura época atual, a nossa futura contemporaneidade terá novamente necessidade do poeta, mas de um poeta genérico, do poeta num papel reencontrado e reinventado, de uma poética como globalidade, como mundialidade do homem, não contra o homem. Somente o poeta pode inventar e ensinar o mundo-palavra, a relação entre a localiteralidade e a globometaforicidade, a colocação em palavras do mundo em ruptura. Portanto, não são as relaçóes da(s) escrita(s) que colocam os verdadeiros problemas, mas uma espécie de nova reunificação atlética pelo arco do poeta, o único que pode dizer, pronunciar, estruturar, articular o que nos submerge como fluxo.

Alea: O senhor trabalhou muito na televisão e no rádio, não apenas como jornalista, mas também como diretor. Poderia falar um pouco desse trabalho e dos programas que realizou? Como o senhor analisa as relaçóes entre o intelectual e as mídias no contexto cultural e politico da Romênia?

B.G.: Fui rapidamente atraído, logo após dezembro de 1989, pelo poder da televisão (e das mídias em geral), que parecia se abrir a 
todos, mas que é um poder perverso, pois atrai para captar, para cativar, para tornar cativo, para aprisionar você por todos os meios, pelos seus próprios sonhos, imprópria e artificialmente realizados e, portanto, reproduzidos (como na descrição do poder em Foucault). Eu sou reconhecido como o criador da crônica de TV na Romênia, o país da primeira revolução televisiva, eu me defino como um crítico da televisão e das mídias, assim como um crítico literário ou um crítico de arte, mesmo que a linguagem atual açucarada, perversa, prefira a noção imprópria, colaboradora, cínica, como dizia Bourdieu, de "analista", ou, horribile dictu, de "expert", já que a pretensa "expertise" substituiu em toda parte a experiência (tal como a criatividade, que é adaptaçăo, logo reconhecimento da submissão, substituiu a criação, que é resistência, oposição etc.: reencontremos os bons maniqueístas, os maniqueísmos políticos úteis, os dualismos da luta!). Passei por toda a história da reinvenção da televisão na Romênia, e, portanto, em suma, por todas as ilusôes e todos os fracassos universais ligados à expressão por meio de imagens técnicas, já que o conceito de imagem como tal (veja as irrefutáveis genealogias de Hans Belting, por exemplo) é um artifício técnico: "a imagem" não existe. Rapidamente tomei consciência do fato, que estou sempre tentando explicar, de que a suposta "transição pós-comunista", quer dizer, a recuperação pelo capitalismo exposto à globalização desta zona excomungada do leste europeu, era uma unicidade histórica, logo um privilégio existencial. Mesmo agora, em termos de supostas "políticas anticrise" (foi por isso que escrevi $A$ Contra-Crise), nestas periferias próximas, justapostas, imediatas (que se diferenciam das periferias distantes, que poderiam tornar-se polares, surpreendentes, quer dizer, continuadoras em termos de dominação, como o Brasil, por exemplo!) como a Romênia, por exemplo, ou a Grécia, experimenta-se, politicamente. Nós vivemos aqui - e eu, ao menos, tento também pensar - processos de vanguarda da história política caminhando em direção a novas tentativas de governança global. Retomando a questão das ilusôes das mídias, vivemos aqui a globalização da televisão, a tele-governança midiática. Agora, não há mais nada a fazer na televisão, tudo segue a mesma receita cínica, não se pode nem mais criticar, deveríamos escrever o mesmo artigo, a mesma crônica televisiva a cada dia. Continuo a trabalhar um pouco no rádio, que prefiro, mas gostaria de fazer mais, não televisão, porém, que seguiu as análises de Deleuze: somente palavras de ordem. A televisão está 
estruturalmente acabada, é justamente por isso que ela só pode se repetir, só pode se reproduzir infinitamente. Tornou-se uma espécie de aplicação, de software automático, dos fluxos imateriais que não nos guiam mais massivamente, ostensivamente, pelos aparelhos visíveis, e portanto analisáveis, criticáveis, mas nos enquadram insensivelmente, de uma maneira capilar e em filigrana, por todas as telas cada vez menores, mais imateriais e mais inobserváveis, já integradas e somatizadas, com as quais nos entupimos. Perdemos mais uma vez a batalha das imagens, é o artista que deve levá-la adiante ou, mais particularmente, inventá-la, já que ela náo é mais a mesma, que a guerra também se modificou. E cabe ao poeta ligar, articular (logos), estruturar, dizer as coisas de uma vez, em um sopro, aquilo que sentimos sem ver, como uma condição pós-traumática cujo traumatismo somos incapazes de identificar.

Tradução do francês de Jéssica Teixeira Magalhães (Mestranda em Literaturas de Lingua Francesal UFRJ) 